\title{
Born Globals From the Resource-Based Theory: a Case Study in Colombia
}

\author{
Alexander Tabares', Claudia Alvarez², David Urbano ${ }^{3}$
}

\begin{abstract}
This paper describes how a born global firm goes into international market from inception at its early years. The objective of this paper is to analyze from the resource-based theory how a born global firm engages in international market. This empirical investigation has been carried out as an explorative single-case study, a high-tech firm, Digital Partner, based in Medellin, Antioquia. The main findings of the research show that organizational capabilities based on intellectual capital are crucial for the development of a born global. Thus, capabilities such as entrepreneurship, global vision, internationally market knowledge, learning management, IT capabilities, technological innovation, collaborative work, networks and customer orientation are recurrent and they correspond to other similar research results. Contributions of the study are both academic (for the advance of the research in born global field) and practical (for the design of governmental policies to foster born global firms).
\end{abstract}

Keywords: born global firms; resource-based theory; intellectual capital: case study; medellin-colombia.

\footnotetext{
'Economics and Management Sciences, Universidad de Medellin, Carrera 87 N³0-65 Medellín, Colombia. e-mail: atabares@udem.edu.co ${ }^{2}$ School of Management, Universidad EAFIT, Carrera 49 N 7 Sur-50, Medellín, Colombia. e-mail: calvar44@eafit.edu.co ${ }^{3}$ Department of Business, Universitat Autonoma de Barcelona,Edifici B, Campus UAB, 08193 Bellaterra (Barcelona), Spain. e-mail: david.urbano@uab.es
} 


\section{Introduction}

In the context of a globalized world, the company internationalization process has significantly been changing in the last years. Some dynamic and newly established firms are becoming international at founding or very shortly thereafter challenging the validity of the traditional perspective (Knight and Cavusgil, 2004) in which a firm follows a specific-regular, slow and evolutionary process to get markets overseas. These early internationalizing firms which are involved in a context of economic integration, modern information and communication technologies and market liberation increasingly begin to operate in international markets in substantial numbers worldwide and they can achieve considerable foreign success basically because they leverage a set of intangible resources and other key organizational capabilities (Rialp and Rialp, 2006).

This new trend has been studied within the internationalization-entrepreneurship framework under the name of international new ventures, global start-ups, bornglobal firms or instant internationals, but it is the term Born Globals the most used and accepted (Cavusgil and Knight, 2009). According to some authors such as Jones (1999), Autio, Sapienza and Almeida (2000), Bell, McNaughton, Young and Crick (2003), Sharma and Blomstermo (2003), these new early internationalizing firms seem to be from technologyintensive companies. Nevertheless, consistent research developed in United States, Europe, Asia, Latin America and Australia in the last years reveals that the existence and further development of these early internationalizing firms are attached not necessarily to high-tech sectors but also to other sectors either smaller knowledge-intensive and/or smaller service-intensive firms which just make an intensive use of knowledge to develop new offerings, improve productivity, introduce new methods of production or improve service delivery (Aspelund and Moen, 200I; Dib, Da Rocha and Da Silva, 20 I 0; Lopez, Kundu and Ciravegna, 2009; Knight and Cavusgil, 2004; McDougall, Oviatt and Shrader, 2003; Moen and Servais, 2002; Honorio, 2009).

Understanding the importance and the steady growth of this topic worldwide, the objective of this empirical exploratory study is to analyze from the resource-based theory how a born global firm engages into international market from inception at its early years.

This research makes some contributions. First, it is investigated the phenomenon of early internationalization in Latin America, region where there are just a few studies. Second, it is determined how a born global firm is created in the Colombian context. Third, it is examined the mentioned phenomenon through the lens of a recognized and accepted theory. Fourth, it is highlighted the importance of intellectual capital as well as key organizational capabilities as trigger factors for early internationalization and it is proposed an exploratory model which offers critical corresponding linkages between the intellectual capital assets and the key organizational capabilities in order to get early internationalization.

The paper structure is as follows. At the beginning, it is offered a theoretical framework. After, it is presented the methodology. Later, a general analysis is done and a discussion of the results is offered. Finally, some conclusions as well as some implications including future research directions are outlined.

\section{Theoretical Framework}

Current markets are characterized by globalization and growing economic integration, where information and communication technologies are available and the market liberation as well as the competition are steadily increasing (Coviello and Munro, 1995). The internationalization process could not be strictly viewed as a neoclassical market with many independent suppliers and customers (Johanson and Vahlne, 2009) where firms choose the optimal mode for entering a market by analyzing their costs and risks based on market characteristics and taking into consideration their own resources. Since two decades, a new form of accelerated internationalizing firms has challenged the traditional views and models of analyzing the internationalization basically because these kinds of companies follow a very different pattern in which they regularly use new technologies and distinctive intangible assets (Cavusgil and Knight, 2009) as valuable resources and capabilities to become successful (Rialp and Rialp, 2006). This early internationalization phenomenon is firstly studied within the company internationalization-entrepreneurship field at the beginning of 90's as a research gap response since the firm internationalization process was exclusively considered as a question of big and well-structured multinationals and not as an issue of small and medium enterprises (SMEs). Indeed, in 70's and 80's the SMEs that commercialized internationally were not considered at all or simply they were exceptional studies (Oviatt and McDougall, 1994).

Due to the great importance that awakes this new perspective in 90 's, different authors begin to analyze and then characterize these firms. They are commonly defined as companies that conduct international business from inception at early years, seeking to derive significant competitive advantage from the use of resources, capabilities and the sale of outputs in multiple countries (McDougall, Shane and Oviatt, 1994). Although these firms are called under different names such as Born Global Start-ups, High Technology Start-ups and International New Ventures, it is 
Born Globals the name that is the most accepted (Cavusgil and Knight, 2009).

Under this name, the Born Globals are characterized as firms exporting on average only two years after foundation and achieving 76 percent of their total sales through exports (Rennie, 1993). Following Knight and Cavusgil (2004) and Madsen, Rasmussen and Servais (2000), Born Globals are also defined as firms that have reached a share of foreign sales of at least 25 percent after having started export activities within three years after their birth. Some authors, such as McDougall and others (1994), Roberts and Senturia (1996), Zahra, Ireland and Hitt (2000) and Sharma and Blomstermo (2003), initially describe Born Globals as a business that mainly comes from the high-tech sector. Conversely, some other consistent research studies in high income countries (according to the World Bank criterion for classifying economies) such as Australia, Denmark, Norway, and the US reveal that the existence and further development of Born Globals are phenomena not only attached to new hightech sectors but also to a wider spectrum of sectors and markets, including manufacturing and/or services (Knight and Cavusgil, 2004; McDougall and Others, 2003; Moen and Servais, 2002).

Some recent studies in other high income countries, such as Israel, South Korea and Chile (Efrat and Shoham, 2012; Park and Rhee, 20I2; Poblete and Amoros, 20I3;Ahmed and Rock, 2012) and upper-middle income ones, such as China, Brazil, India, South Africa, Colombia, Costa Rica (Tan and Zeng, 2009; Zhang, Tansuhaj and Mccullough, 2009; Dal-Soto , Paiva and De Souza, 2007; Perin, Sampaio and Hooley, 2007; Kim et al., 20I I; Khavul, Prater and Swafford, 20 I2; Escandon, Vargas and González-Campo, 20 I3; Lopez et al., 2009), show evidence of increasing scholar studies in a wide range of business environments, industries and economies.

Regarding to theoretical explanations and frameworks on Born Globals, scholars have firstly analyzed them extensively from three of them: the Theory of Gradual Stages, the Theory of Direct Investment and the Network Perspective. Sometime later, many researchers begin to argue that the accelerated formation process of Born Globals is not well explained by the existing international business theories (Knight and Cavusgil, 2004; McDougall et al., 1994; Cavusgil and Knight, 2009). As a consequence, other scholars try to explain this phenomenon from other perspectives and this is how other five major theoretical frameworks are distinguished: the Resource-based theory, the Capability View, the Organizational Learning Theory, the Innovation Theory and the International Entrepreneurship Perspective. All the academic attempts to understand this phenomenon have long contributed to the scholarly discussion and have permitted to characterize these kinds of early internationalizing firms as small organizations with limited financial and tangible resources that engage into international business successfully due to some key intangible resources and organizational capabilities such as an international entrepreneurial orientation, a strong international managerial outlook, a differentiation strategy based on superior product quality, a market and marketing orientation, a learning strategy, a technological leadership and strong international network relationships among others (Bell et al., 2003; Cavusgil and Knight, 2009; Coviello and Munro, 1995; McDougall et al, 1994; Rialp et al., 2005). Accordingly, many scholar studies have commonly concluded that Born Globals could internationalize right from inception or at early years and stay operating basically because of the internal resource managerial commitment combined with key orientations, strategies and capabilities. In order to analyze these inner organizational resources (a set of tangible, intangible and capability assets) that become potential source of competitive advantage in the firm (Barney, 1991; Grant, 1996; Knight and Cavusgil, 2004) this study has chosen the resource-based theory in part because it is precisely one of the theoretical perspectives that permits this inner analysis.

The resource-based theory is born originally as a perspective in strategy management with a book called "the theory of the growth of the firm" (Penrose, 1959), but it is around 30 years after that this management approach gets rich and receives great contributions from some important scholars that build up a strong strategic management field. It is Birger Wernerfelt in his paper "A resource-based view of the Firm" (1984) that this perspective name is coined as ResourceBasedView. On his article, this author supports his principles on some previous research concepts where emphasis is essentially made on the importance of resources and their implications for firm performance. Later on in 1991, the scholar Barney with his academic research contributions presents and develops the core tenets of this theory giving a detailed definition of resources as a potential source of competitive advantage. Precisely, from Barney's framework, the mentioned theory proves to be a strong foundation upon which others continue setting up some important theoretical framework.

As such, in the first decade 1990-2000, different authors help the resource-based theory to grow and get mature. Particularly, Amit and Shoemaker (1993) draw a big distinction on the resource construct and they broaden this concept into resources and capabilities as a source of sustained competitive advantage (Cavusgil and Knight 2009). Similarly, other scholars working on that line widen and extend the research frontiers by subdividing resources in two broad categories and by specifying and describing in a better way the capabilities. Therefore, the resources are 
divided in two categories which are tangible and intangible. On one hand, tangible resources refer to the fixed and current assets of an organization which have a fixed long-run capacity (Wernerfelt, 1984). They include physical location in terms of plant, equipment and machinery, natural resources, raw material, product designs and production techniques and other capital goods and stocks such as debtors and bank assets. On the other hand, the intangible resources refer to abstract assets which are relatively resistant to duplication efforts by other competitors due to the inherent complexity and specificity of their accumulation process which hinders imitability and substitutability in the short/medium term (Fahy, 2000).

These intangible and abstract assets later are named intellectual capital and it is divided into human, structural and relational capital. First, the human capital is defined as the employees' skills and attitudes for solving business problems or for innovating; their know-how, their experience and expertise; it also encompasses how effectively an organization uses its people resources. Second, structural capital is divided into organizational and technological capital. As such, on one side, organizational capital embraces the firm culture, organizational values, internal organizational structures, management styles, organizational learning guidelines and procedures and, on the other side, the technological capital includes research and development processes, production techniques, product technology and regulatory protection such as copyrights and trademarks, patents and trade secrets as well as technological supervision and competitive intelligence projects. Third, relational capital consists of establishing long-term stakeholders' relationships both inside and outside the organization: inner organizational clients, shareholders, employees, customers, suppliers, distribution channel agents, business partners, competitors, private and public institutions, social networks and media (Bontis, 1999; Stewart, 1998; Sveiby, 1997).

Capabilities in turn are in part the result of combining the different intellectual capital assets encompassing complex interactions of individuals, groups, and organizational routines through which all the firm's resources are coordinated (Amit and Schoemaker, 1993). In 200I, this concept is extended by Makadok (200I) who defines a capability as an embedded non-transferable firm-specific ability whose purpose is to improve the productivity of the other resources possessed by the firm. In sum, resources are stocks of available factors that are owned or controlled by the organization, and capabilities are the organization's capacities to deploy resources (Amit and Schoemaker, 1993).

Afterwards, in the last part of the decade 1990-2000 and working on a same line, other important researchers strengthen the resource-based theory with different research studies that consequently broaden it to a point in which this theoretical approach offers foundations for other meaningful new directions and, thus, it gives rise to prominent spin-off perspectives, most notably the knowledge-based view (Grant, 1996) and the dynamic capabilities (Teece, Pisano and Shuen, 1997). By examining the born global phenomenon under the resource-based theoretical framework lens, some born global empirical studies conducted by Oviatt and others (1994), Madsen and others (2000), Aspelund and Moen (200I), Moen and Servais (2002), Rialp and Rialp (2006), Dal-Soto and others (2007), Perin and others (2007), Tan and Zeng (2009), Ahmed and Rock (20I2), Efrat and Shoham (20I2) have shown strong and high interest by applying the so-called Resource-Based View/Theory or its associated conceptual developments as their core theoretical frameworks to describe the inner factors that permit firms to internationalize at early age and to have sustainable competitive advantage.

Later, in the early 2000-2010 decade, a complete and integrative born global literature review (1993-2003) done by Rialp, Rialp and Knight (2005) shows some recurrent features or factors occurring in the internal environment of the firm that seem to engender or facilitate the early internationalization phenomenon. The features or factors commonly appearing in many scholars' papers are from the intellectual nature as well and they can be classified in ten: (I) a managerial global vision from inception; (2) high degree of previous international experience on behalf of managers; (3) management commitment; (4) strong use of personal and business networks (networking); (5) market knowledge and market commitment; (6) unique intangible assets based on knowledge management; (7) high value creation through product differentiation, leading-edge technology products, technological innovativeness (usually associated with a greater use of information technology), and quality leadership; (8) a niche-focused, proactive international strategy in geographically spread lead markets around the world from the very beginning; (9) narrowly defined customer groups with strong customer orientation and close customer relationships; and finally (10) flexibility to adaptto rapidly changing external conditions and circumstances. Afterwards, other studies have complemented this conceptual basis and they conclude that the organizational knowledge, the networks that the firms especially develop in the international markets (Dal-Soto et al., 2007; Park and Rhee, 2012), the market and the customer orientation as well as the organizational learning (Rialp and Rialp, 2006; Weerawardena et al., 2007; Perin et al., 2007; Kim et al. 20II) are also key factors at the early internationalization.

According to the previous and comprehensive review, it is concluded that a critical set of factors determining early internationalization seems to be from intangible nature 
rather than tangible one since these firms tend to lack substantial financial, properties, plants equipment and other physical assets (Cavusgil and Knight, 2009). In this sense, a set of intellectual capital assets, specifically human, structural and relational capital and the strategic combination of them could generate key organizational capabilities difficult to replicate by other competitors, at least in the short-medium term, that in turn permit the companies to get access into international markets from inception at early years. (See figure I).

This model shows that firms that leverage intellectual capital assets and organizational capabilities could achieve considerable foreign market success early in their evolution despite the scarce financial, human and tangible resources that characterize most new businesses (Knight and Cavusgil, 2004; Rialp and Rialp, 2006; Teece et al., 1997). This means that a firm that promotes its intellectual capital human capital at an individual and organizational level; a firm that promotes its structural capital through a strong organizational culture and through an innovating technological process and a firm that promotes its relational capital through a strong network relations with the stakeholders will create valuable, unique, rare and non-substitutable products and goods that will guarantee sustainable competitive advantage in international markets (Rialp and Rialp, 2006; Perin et al., 2007; Dib et al., 20I0, Kim et al., 20II; Park and Rhee, 2012). As it is stated by Barney in 1991, the resources by themselves do not confer a persistent competitive advantage. Thus, it could be argued that firms showing a wider variety of intellectual capital assets such as human, structural and relational capital and the strategic combination of them could create valuable and key organizational capabilities.

Proposition one. The firms with higher intellectual capital assets such as human, structural and relational capital could create valuable organizational capabilities.

\section{Intellectual Capital}

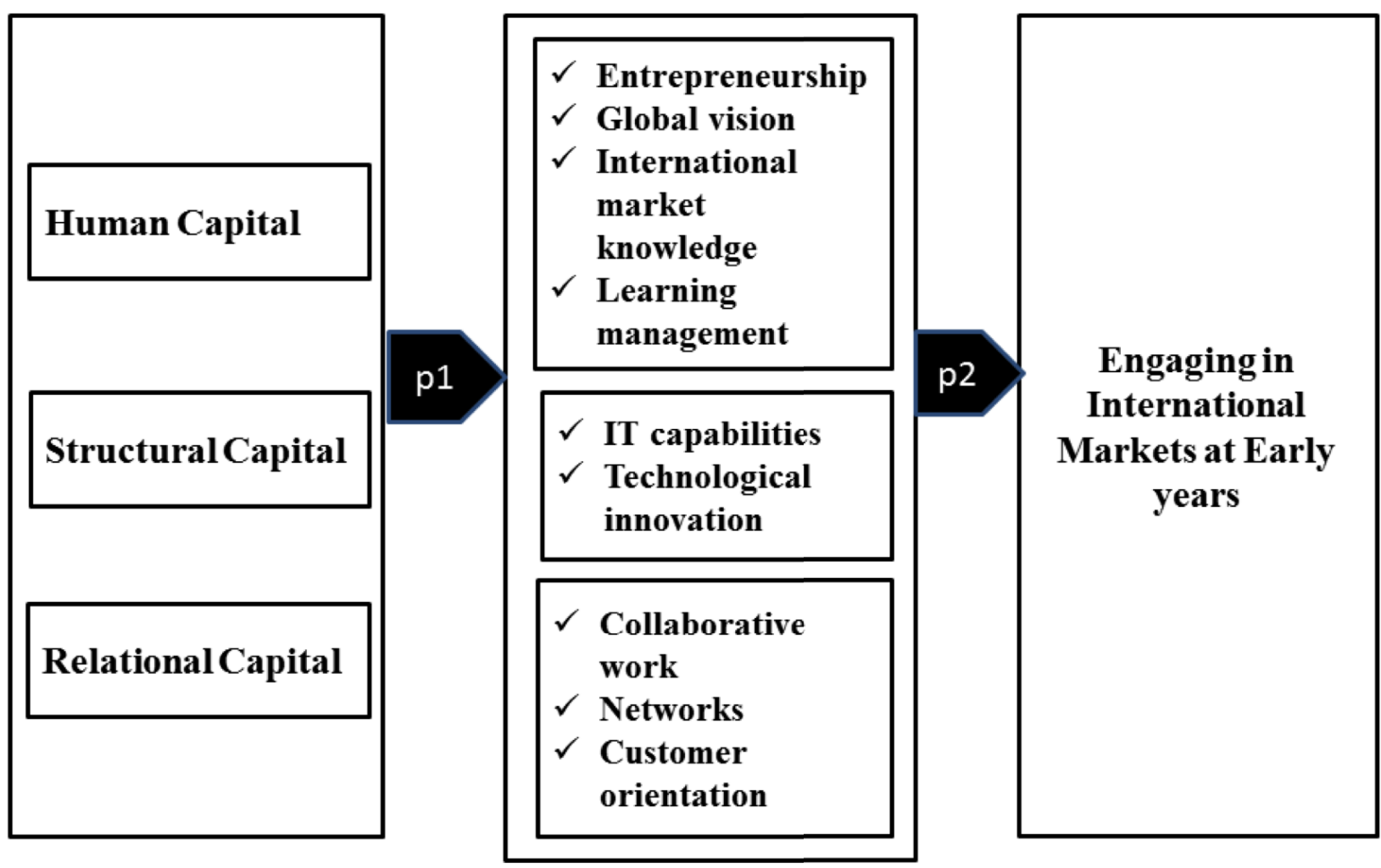

\section{Organizational} Capabilities

\section{Early Internationalization}

Figure I:An exploratory model of early internationalization from the Resource-based theory 
Once a firm owns intellectual capital assets and it is able to transform them into a set of valuable organizational capabilities that are difficult to imitate from competitors, the company can generate sustainable competitive advantage that permits the early internationalization and the lastingness in international markets. Several studies that have previously investigated the relationship between organizational capabilities and the success of early internationalization of firms usually confirm this correspondence (Cavusgil and Nevin, 198I; Cavusgil, 1984, Knight and Cavusgil, 2004, Rialp and Rialp, 2006). In this line, authors such as McDougall and others (1994), Grant (1996), Autio and others (2000), Zahra and others (2000), Aspelund and Moen (200I), Moen and Servais (2002), Dal-Soto and others (2007), Ahmed and Rock (20I2), Efrat and Shoham (20I2), state that the ability to internationalize early and succeed in foreign markets is a function of the internal capabilities of the firm and overall of the organizational capabilities which reflect the ability of the firm to perform repeatedly productive tasks that relate to the firm's capacity to create value through effecting the transformation of inputs into outputs (Teece et al., 1997) and through the integration of specialist knowledge associated with the development of organizational competences and routines (Grant, 1996). In this sense, the organizational knowledge derived from multiple individual sources is greater than the sum of its parts and becomes a key strategic asset. It is not enough for an organization to hire and promote the brightest individuals it can find: an organization must also support and nurture bright individuals into sharing their human capital through organizational learning that involves transferring capabilities so as to extend the firm's performance into new markets, new product categories, and new ways of doing business (Teece et al., 1997). Possession of such organizational capabilities helps firms to attenuate their liabilities of foreignness and newness (Oviatt and McDougall, 1994). Consequently, it could be argued that firms with a certain degree of organizational capabilities could become international at early years.

Proposition two. The firms with higher organizational capabilities could engage in international markets at early years.

\section{Methodology}

This empirical research has been carried out as an explorative fieldwork in an Antioquia company, more exactly in Medellin, city that is chosen in 2012 as one of the world's most innovative city in a competition organized by the non-profit Urban Land Institute. Under this innovating city context, this company choice is the result of a filter research where Commerce Chamber of Medellin city and two organizations such as Tecnnova and Ruta N, organizations in charge of promoting and leading innovating start-ups, assure that the company has a profile matching the born global one. In addition, this high tech service firm has been selected after having defined some features that a Born Global should fulfill. That is to say, a firm that is born globally from inception and that becomes international in its first two years and a half as well as being exporting more than 25 percent of its products and services abroad. Due to its instant presence on several continents right from inception, its micro-firm characteristic (four employees) and virtual character (all business activities are solely carried out through the World Wide Web), Digital Partner could be considered an extreme case (Yin, 2009) worth of being studied in the context of Born Globals. Constant and fluid access to firms' archival data and the founder/owner willingness to collaborate in this study has also been helpful at selecting the firm case.

In order to ensure rigor in this qualitative methodology (Yin, 2009), it is followed the construction of validity and reliability in terms of primary and secondary reports relating to broader criteria such as construct validity, internal validity, external validity and reliability (Gibbert and Ruigrok, 20l0). Once the firm is selected based on the parameters above referred and following the criteria specified in the theoretical framework, the data collection is carried out from different sources assuring a triangulation strategy that enables to observe the selected phenomenon from different angles. Previously, it is consulted secondary information in internet such as press reports, the company website where it is reviewed its online forums, its service and product range as well as its blogs and its Facebook profile. Then, it is obtained primary information based on depth semi-structured interviews that researchers have personally conducted with the general manager-founder: each interview has been recorded on digital form (with the permission of the informant) and subsequently transcribed, thus, allowing the researchers sharing the scripts to the manager and some peers in order to guarantee consistency and accuracy (Denscombe, 2003). During and after interview sessions, data have been complemented by following up some meetings and workshops in the researched firm as well as communication via e-mail with the manager and information consulted in some company reports. Practically,

ISSN: 07 I8-2724. (http://www.jotmi.org) 
the original data collection planned design is executed without many changes excepting some questionnaire item modifications relating to some late findings in the theoretical framework reviewing.

Regarding to internal validity actions assuring logical and coherence among variables and results, it is proposed an exploratory early internationalization model which is derived from a comprehensive literature review offering some causal relationships between variables and outcomes which in turn are compared and supported on previous scholar studies that match patterns identified in the present case study. In this line, the internal validity is also assured when a recognized and well accepted theory is selected as theoretical lens by which the findings may be interpreted and analyzed on an unbiased basis. Concerning to external validity that guarantees generalizability, it is chosen a singlecase which could serve as a basis for empirically testing previous theoretical explanation of the phenomenon being researched (Eisenhardt, 1989; Rialp et al., 2005; Yin, 2009). It is acknowledged that a study concentrating on one company in a specific business context could be limited with respect to statistical generalizability. Nonetheless, the single casestudy approach offers the opportunity for observing and describing a research phenomenon in a way that allows analytical generalizations (Laurila, 1997).
In relation to reliability that assures transparency and replication, each stage of this case-study methodology has followed the procedures recommended in literature (Yin, 2009) for a four-month period. The case study database, in which data such as interview transcripts, preliminary conclusions, and the information collected during the study, are organized and kept to be available for later investigations or even other investigators to facilitate the replication of the case study (Gibbert and Ruigrok, 2010). It is also followed rigorous research procedures by producing a case study protocol which specifies how the entire case study has been conducted (Yin, 2009): First, the case study is defined and designed. Second, it is well-prepared to collect the relevant and required information efficiently. Third, the case study evidence is analyzed in two phases and finally it is offered some conclusions, recommendations and implications based on the evidence (See table I).

In oeder to strengthen reliability, the research case study is divided in two parts: one is a descriptive phase and the other one is an analytical one since they clearly represent different stages of the research process.

\begin{tabular}{|l|l|}
\hline ASPECTS & DESCRIPTION \\
\hline Objective & $\begin{array}{l}\text { Describe how an early internationalizing firm goes into international market from inception } \\
\text { at early years }\end{array}$ \\
\hline Company & Digital Partner, a high-tech firm located in Medellin, Colombia (2009). \\
\hline Information Source & $\begin{array}{l}\text { Primary: Owner/founder of the firm } \\
\text { Secondary: Press reports, Digital Partner's website, online forums, mobile applications, blogs, } \\
\text { Facebook, brochures. }\end{array}$ \\
\hline $\begin{array}{l}\text { Information Gathering } \\
\text { Method }\end{array}$ & $\begin{array}{l}\text { Data Reviewing: Firm background, its growth and born process; firm features and service } \\
\text { portfolio, customers' profile; firm business model } \\
\text { Duration: two (2) months } \\
\text { Interviews: Interviews with the owner/founder of the firm: three (3) sessions based on a } \\
\text { semi-structured questionnaire. } \\
\text { Duration: One and a half during three (3) months }\end{array}$ \\
\hline Field Work & Four (4) months \\
\hline Analysis Procedure & Two (2) months \\
\hline
\end{tabular}

Table I. Case study protocol

ISSN: 07 I 8-2724. (http://www.jotmi.org) 


\section{Results}

The firm is called Digital Partners Group.This firm is expert at developing mobile technology applications and it wants to be the Latin America leader, mainly in Mexico and Brazil, in the near future according to its vision. This company is in part the result of an entrepreneurship intention of a professional in management with specialization in marketing and international affairs who explores the digital commerce on his free time. At his early years at college, the internet technology is a reality worldwide and obviously it arrives to Medellin strongly around 1996. In that year, he early gets involved into digital projects and, at the end of his career in 200I, he ends up defining a product in digital strategy; specifically, he plans how to do a digital marketing campaign for a local firm. In retro perspective, it is this research project and his hobby for the recent technology and his steady self-learning on the digital commerce what opens his path through a rigorous work line that brings him expertise and experience. Actually, he shows a big evidence of entrepreneurship with the digital strategy he starts up in 200I. From that moment and on, he starts over different projects in which digital commerce is always linked to.

Later on, this Digital Partner owner-founder has the chance to travel to Brazil and he works over there for Renault around 3 years. When the contract is over, he comes back to Colombia but he does not have any job proposal. Then, he decides to develop his own business project: this new entrepreneurial idea comes into the analytical mobile usability. He proposes a strategy for social commerce which, in his words, is the result of a "constant learning management, knowledge that is accumulated and later it is integrated and used". In this sense, this founder is always under self-training reading and studying specialized magazines, newsletters, forums, social networks and start-up events in Colombia, Europe and US. Once he becomes his own manager, he develops two or three projects in association with other people. When the I-phone is invented, he decides to work hard on the creation and on the developing of mobile tech applications. Later, he associates with a college partner at the end of 2008 and they start up this consulting firm. Since its creation, the firm becomes international selling its services of consulting, designing and offering technical and commercial support not only to Colombia but also to US. The year after, the firm broadens its international market to Singapore, Spain, and Mexico.
Since 2009, they both have built up important collaborating networks in mobile technology business development with direct support from platform and people in Mexico, Central America, Puerto Rico, Colombia, Venezuela, Ecuador, Peru, Chile, Argentina, Brazil and US (Miami/San Francisco). In the mid-term future, the firm forecasts great chances to apply technology to the daily activities of all people since the mobile phone penetration in Latin America has been 4 times higher than Internet due to the fact that the number of devices generally exceeds the number of inhabitants. It is relevant to say that, although the team at Digital Partners Group has added not more than 15 year experience in the design, construction, implementation and marketing of digital products, and about 10 years exclusively for mobile technology, the firm that is created in 2009 has accumulated and gathered reputation by working with over 100 customers in II different markets with big companies such as Google and Microsoft.

Following the parameters necessary for the analysis of a case-study (Yin, 2009), it is chosen a born global firm which fulfills the necessary features according to the parameters described in the theoretical framework and later this is conducted under the lens of the resource-based theory. As such, it is supported that the company as a Born Global has not necessarily grown into its local market to expand operations near countries later but it has reached other economies from inception having certain grade of competitive advantage. Also, it is remarkable to take evidence that many intangible resources rather than tangible ones that have been reviewed throughout the research have enabled the company to create some organizational capabilities that in turn permit to reach global internationalization at early stage having transactions in far countries in Europe and Oceania including Latin American countries and United States. In this sense, the firm hinders imitability and substitutability in the short and medium term since it deploys intangible resources and organizational capabilities that are by nature relatively resistant to duplication efforts by other competitors due to the inherent complexity and specificity of their accumulation process (Fahy, 2000).

According to an international entrepreneur and co-founder of Digital Partner, some factors have been keys to the early internationalization and to keep the firm competitive in the country and outside. These triggers are all practically from intangible nature and correspond to important intellectual capital: the two founders/owners claim basically six: "(I) their reciprocal empathy and confidence; (2) the international experience and some important relations that one of the founders has established abroad permitting to open new markets; (3) the global and international vision,

ISSN: 07 I8-2724. (http://www.jotmi.org) 
letting the firm understand the dynamism and the demand in real time; (4) based on this global and international insight, the firm has been able to be flexible and adaptable to the national and mostly to the international market; (5) the close contact with clients has empowered the firm to meet to what people and other companies need and require (6) the good quality and the specialized products and services have enabled the firm to respond to what people and other companies want and desire".

In order to amply the case study evidences in a better way and related to the theoretical framework findings, it is described in detail some of the intellectual capital assets and organizational capabilities that were found.

First, the human capital resource is basically defined in the personal, strategic and organizational skills that this entrepreneur has built up through academic formation, high market knowledge, international experience and good communicative competences specifically of English language which is considered a vital tool for doing business abroad and all over the world, chiefly in United States and Europe. Indeed, this language competence and his technical knowledge have given him the chance to create personal contacts and relations, experience and global insight which he has well complemented by undertaking foreign trips to high tech fairs and congresses all around the world as well as being updated through every day technical reading. Also, it is evident in this study the fact that the founder had already worked before starting other businesses which undoubtedly have given him wide international experience and entrepreneurial capabilities. Furthermore, it is seen that values and attitudes such as taking risks in new markets, having a steady self-learning process and a global insight have also influenced.

Second, the structural capital resource, which is subdivided in organizational and technological, is basically defined, on one side, into its micro organizational culture that promotes confidence, empathy, collaborative teamwork and an excellent environment of loyalty and, on the other side, into a learning management where innovation and the high degree of flexibility in organizing tasks and processes enable them to adapt to the changing needs of the environment.

Third, relational capital is defined into the customer orientation that is built up from the client loyalty and the long-term customer relationships that have enabled the firm to create a value creation process where it is noted the service differentiation, high quality, good service, timely delivery and product adaptation to customer requirements. At the same time, the company has been able to establish important networks both locally and globally almost from the birth that has let its rapid internationalization.
Consequently, this case study analysis under this resourcebased theory shows evidence that intellectual capital, exhibited mainly in the human capital but complemented with the structural and the relational, is a distinguishing intangible resource feature that allows the company to obtain important organizational capabilities such as entrepreneurship, global vision, international market knowledge, learning management, IT capabilities, technological innovation, collaborative work, networks and customer orientation that in turn enable the firms to internationalize rapidly fulfilling the parameters of a Born Global and confirming and matching other born global case study approaches done in United States, Europe, Australia, Asia and in Latin America. In this sense, scholars, such as Knight and Cavusgil (2004), Rialp et al. (2005), Weerawardena et al. (2007), Khavul et al. (20/2), Poblete and Amoros (2013), Escandon et al. (2013) find similar factors in their studies showing evidence of common and recurrent features not only at specific regions but also in different continents.

\section{Conclusions}

This research has been done as an exploratory singlecased approach, using the resource-based theory, to analyze how a born global firm engages into international market from inception at its early years. Although this early internationalization phenomenon has been increasingly studied worldwide, there is not still enough scholar research regarding to this field in Latin America. After a literature review, it is found that only a few studies have been conducted in countries such as Brazil, Chile, Colombia and Costa Rica. Then, the first contribution of this research is to show more evidences of Born Globals in the region particularly in Colombia and analyze their processes and dynamism to engage into international markets at early years. Thus, this research could offer a better idea of this phenomenon in Colombia and in the region in order to give feedback in the academy and in the companies. Furthermore, it is reviewed the case study under a recognized theoretical framework that permits to assess the internal resources in the acquisition of early internationalization and competitive advantage.

Inthissense,findingsshowstrong evidence ofintellectualcapital and organizational capabilities in born global performance and they show correspondence to other important scholar studies worldwide. Factors such as entrepreneurship, global vision, international knowledge, market knowledge, learning management, IT capabilities, technological innovation, collaborative work, networks and customer orientation are recurrent in this study and they correspond to similar traits that many other research results have concluded on this topic. Particularly, by reviewing and analyzing the model proposed here and its associated propositions, it is 
concluded that Born Globals require mostly entrepreneurial orientation with managers having global vision, international experience and specific knowledge as well as a collection of capabilities at the strategy and organizational-culture levels of the firm that trigger early adoption of internationalization and success abroad.

Although the results can be considered relevant for empirical contexts overall in future investigations in Colombia, some limitations may be perceived. One is that the resourcebased theoretical framework should be extended into others perspectives not only to verify the findings but also to consider dynamic capabilities that respond to changing environments and permit the firm to create and maintain valuable, rare, difficult to imitate and imperfectly substitutable resources.Another issue that should be considered in future line work is the combination of qualitative and quantitative methods in order to set strong theoretical constructs that allow a better understanding and a good measuring of the internationalization process for born-global firms.

On the other side, future line directions require further research studies that compare the dynamics of Born Globals from this part of the world with the United States, Europe, Asia and Australia as well as to participate jointly with research groups from universities with high trajectory. Moreover, understanding the great importance of these common factors in Born Globals, at least detected in the correspondence of this study with many others, it is required to design training programs that encourage entrepreneurs to build up skills and abilities in international knowledge and global vision that, in turn, enable them to cope with the global market, which is characterized by being highly competitive and to boost international networks basic elements for the creation of Born Globals.

Finally, this study could be basis for later research studies to compare other companies both local and regionally as well as to be compared with some studies made in USA, Europe, Asia and Australia on the same descriptive line. If studies similar to this one could make possible the identification of the factors that trigger and give meaning to the Born Globals, surely they would serve as a reference in scholar and in business purposes.

\section{Acknowledgments}

Claudia Alvarez and David Urbano acknowledge the financial support from the Projects ECO2013-44027-P (Spanish Ministry of Economy \& Competitiveness) and 2014SGR-I626 (Economy \& Knowledge Department-Catalan Government).

\section{References}

AHMED, S.A., Rock, J. (2012). Exploring the relationship between export intensity and exporter characteristics, resources and capabilities: evidence from Chile. Latin American Business Review, 13(I), 29-57. doi: I0.1080/I0978526.20/2.673423

AMIT, R., Schoemaker, P. (1993). Strategic assets and organizational rent. Strategic Management Journal, 14, 33-46. doi:10.1002/smj.4250I40I05

ASPELUND, A., Moen, $\varnothing$. (200I). Generation perspective on small firms internationalization: from traditional exporters and flexible specialists to born globals. Advances in International Marketing, II, 197-225. doi:10.1016/s I4747979(0I) II02I-5

AUTIO, E., Sapienza, H.J., Almeida, J.G. (2000). Effects of age at entry, knowledge intensity, and imitability on international growth. Academy of Management Journal, 43(5), 909-924. doi: $10.2307 / 1556419$

BARNEY, J. (199I). Firm resources and sustained competitive advantage. Journal of Management, 17(I), 99120. doi:10.1177/014920639101700108

BELL, J., Mcnaughton, R., Young, S., Crick, D. (2003). Towards an integrative model of small firm internationalisation. Journal of International Entrepreneurship, I(4), 339-362. doi: $10.4337 / 97808579336 \mid 4.00015$

BONTIS. (1999). Managing organizational knowledge by diagnosing intellectual capital:framing and advancing the state of the field. International Journal of Technology Managemet, 18, 433-462. doi: 10.1016/b978-0-7506-7475-I.50006-3

CAVUSGIL, S., Knight, G. (2009). Born Global Firms: a new international enterprise. Business Expert Press.

CAVUSGIL, S., Nevin, J.R. (198I). Internal determinants of export marketing behavior:an empirical investigation. Journal of Marketing Research, I I4-I I9. doi: I0.2307/3 I5I 322

CAVUSGIL, S. (1984). Differences among exporting firms based on their degree of internationalization. Journal of Business Research, 12(2), 195-208 . doi:10.1016/01482963(84)90006-7

COVIELLO, N.E., Munro, H.J. (1995). Growing the entrepreneurial firm: networking for international market development. European Journal of Marketing, 29(7), 49-6I. doi: I0.1 I08/03090569510095008 
DAL-SOTO, F., Paiva, E. L., De Souza, Y.S. (2007). Analysis of organizational competences in the internationalization of leather-footwear chain companies. RAE Revista de Administracao de Empresas, 47(3), 40-52. doi:10.1590/ s0034-75902007000300004

DENSCOMBE, M. (20I0). The good research guide: for smallscale social research projects. 2. ed. Open University Press.

DIB, L. A., Da Rocha, A., Da Silva, J. F. (2010). The internationalization process of Brazilian software firms and the born global phenomenon: Examining firm, network, and entrepreneur variables. Journal of International Entrepreneurship, 8(3), 233-253. doi:10.1007/s 10843-0100044-z

EFRAT,K.,Shoham,A.(20I2). Born global firms: the differences between their short- and long-term performance drivers. Journal of World Business, 47(4), 675-685. doi:10.1016/j. jwb.2012.01.0I5

ESCANDON, B., Vargas, G. M., Gonzalez-Campo C. (20/3). Determinants of international results from recently created SME's in Colombia. Innovar, 23(49), 17-29. doi: not registered

EISENHARDT, K. (1989). Building theories from case study research. Academy of Management Review, I4(4), 532-550. doi: $|0.4| 35 / 978|4| 2986274 . n \mid$

FAHY, J. (2000). The resource-based view of the firm: some stumbling blocks on the road to understanding sustainable competitive advantage. Journal of European Industrial Training, 24(2), 94-104. doi: I0.1 I08/030905900 I032 I06 |

GRANT, R. (1996). Toward a knowledge-based theory of the firm. Strategic Management Journal, I7(I), 109-122. doi: I0.1002/smj.425017IIII0

GIBBERT, M., Ruigrok, W. (2010). The what and how of case study rigor: three strategies based on published work. Organizational Research Methods, 13, 710-737. doi:10.1 177/ 1094428109351319

HONORIO, L.C. (2009). Strategical and organizational determinants of the internationalization degree of Brazilian companies. RAE Revista de Administracao de Empresas, 49(2), I62-I75. doi: I0.1590/s0034-75902009000200004

JONES, M.V. (1999). The internationalization of small hightechnology firms. Journal of International Marketing, 7(4), $|5-4|$.
JOHANSON, J., Vahlne, J. (2009). The Uppsala internationalization process model revisited: from liability of foreignness to liability of outsidership. Journal of International Business Studies, 40(9), I 1 I I- | 43 I. doi: I 0. 1057/jibs.2009.24

KHAVUL, S., Prater, E., Swafford, P.M. (20I2). International responsiveness of entrepreneurial new ventures from three leading emerging economies. International Journal of Operations and Production Management, 32(10), II47| |77. doi:|0.1 |08/0|44357|2| |274503

KNIGHT, G., Cavusgil, S. (2004). Innovation, organizational capabilities and the born-global firm. Journal of International Business Studies, 35(2), 124-141. doi:10.1057/palgrave. jibs.840007I

KIM, D., Basu, C., Naidu, G. M., Cavusgil, E. (20II). The innovativeness of born-globals and customer orientation: Learning from Indian born-globals. Journal of Business Research, 64(8), 879-886. doi: I0.1016/j.jbusres.2010.09.008

LAURILA, J. (1997). The thin line between advanced and conventional new technology:A case study on paper industry management. Journal of Management Studies, 34, 219-239. doi: I0.1 II I/I467-6486.00049

LOPEZ, L. E., Kundu, S. K., Ciravegna, L. (2009). Born global or born regional evidence from an exploratory study in the Costa Rican software industry. Journal of International Business Studies, 40(7), I 228-I 238. doi: I 0. 1057/jibs.2008.69

MADSEN, T.K., Rasmussen, E., Servais, P. (2000). Differences and similarities between born globals and other types of exporters. Emerald Group Publishing Limited. 10, 247-265. doi:I0.10|6/s|474-7979(00) I00I3-4

MAKADOK, R. (200I). Toward a synthesis of the resourcebased view and dynamic-capability views of rent creation. Strategic Management Journal, 22(5), 387-40I. doi: 10.1002/ smj.I58

MCDOUGALL, P.P., Oviatt, B.M., Shrader, R.C.(2003). A comparison of international and domestic new ventures. Journal of International Entrepreneurship, I(I), 59-82. doi: not registered

MCDOUGALL, P.P., Shane, S., Oviatt, B.M. (1994). Explaining the formation of international new ventures: the limits of theories from international business research. Journal of Business Venturing, 9(6), 469-487. doi:10.1016/08839026(94)90017-5 
MOEN, Ø., Servais, P. (2002). Born global or gradual global? Examining the export behavior of small and medium-sized enterprises. Journal of International Marketing, 10(3), 49-72. doi:I0.I509/jimk.10.3.49.19540

OVIATT, B. M., McDougall, P.P. (1994). Toward a theory of international new ventures. Journal of International Business Studies, 25(I), 45-64. doi:I0.1057/palgrave.jibs.8490I 93

PARK, T., Rhee, J. (20I2). Antecedents of knowledge competency and performance in born globals. Management Decision,50(8), | 36 |- | 38|.doi: I0.| |08/0025 |74| | | | 26| 97 |

PENROSE, E. (1959). The theory of the growth of the firm. Oxford University Press.

PERIN, M.G., Sampaio, C.H., Hooley, G. (2007). Impact of company resources in innovation performance. RAE Revista de Administracao de Empresas, 47(4), 46-58. doi:10.1590/ s0034-75902007000400005

POBLETE, C., Amorós, J.E. (20/3). Determinants in the internationalization strategy for SMEs: The case of Chile. Journal of Technology Management and Innovation, 8(I), 97I06. doi: I0.4067/s07/8-272420I3000I000I0

RENNIE, M. (1993). Global competitiveness: born global. McKinsey Quarterly, 4, 45-52. doi: not registered

RIALP, A., Rialp, J. (2006). Faster and more successful exporters: an exploratory study of born global firms from the resource-based view. Journal of Euromarketing, I6(I-2), 7I-86. doi:I0.I300/j037vI6n0I_06

RIALP,A., Rialp, J., Knight, G. (2005). The phenomenon of early internationalizing firms: what do we know after a decade (1993-2003) of scientific inquiry?. International Business Review, I4(2), I47-I66. doi:I0. I0I6/j.ibusrev.2004.04.006

RIALP, A., Rialp, J., Urbano, D., Vaillant, Y. (2005). The bornglobal phenomenon: A comparative case study research. Journal of International Entrepreneurship, 3(2), I33-17I. doi: 10.1007/s 10843-005-4202-7

ROBERTS, E.B.,Senturia,T.A.(1996). Globalizing the emerging high-technology company. Industrial Marketing Management, 25(6), 49I-506. doi: $10.1016 / s 0019-850$ I(96)00072-7

SHARMA, D.D., Blomstermo, A. (2003). The internationalization process of born globals: a network view. International Business Review, 12(6), 739-753. doi:10.1016/j. ibusrev.2003.05.002
STEWART,T.A. (1997). Intellectual capital: the new wealth of organizations. New York: Bantam Doubleday/Currency.

SVEIBY, K.E. (1997). The new organizational wealth: managing and measuring knowledge-based assets. San Francisco: Berrett-Koehler.

TAN, J., Zeng, Y. (2009). A stage-dependent model of resource utilization, strategic flexibility, and implications for performance over time: Empirical evidence from a transitional environment.Asia Pacific Journal of Management, 26(3), 563-588. doi: 10.1007/s 10490-009-9|40-9

TEECE, D., Pisano, G., Shuen, A. (1997). Dynamic capabilities and Strategic management. Strategic Management Journal, 18(7), 509-533.

WEERAWARDENA, J., Mort, G. S., Liesh, P., Knight, G. (2007). Conceptualizing accelerated internationalization in the born global firm: a dynamic capabilities perspective. Journal of World Business, 42(3), 294-306. doi:I0.1002/(SICl)10970266(I 199708) I 8:7<509::AID-SMJ882>3.0.CO;2-Z

WERNERFELT, B. (1984).A resource based-view of the firm. Strategic Management Journal, 5(2), I7I-I80. doi:I0.1002/ smj.4250050207

YIN, R. K. (2009). Case study research: design and methods. Beverly Hills, v. 5: Sage.

ZAHRA, S. A., Ireland, R.D., Hitt, M. A. (2000). International expansion by new venture firms: International diversity, mode of market entry, technological learning, and performance. Academy of Management Journal, 43(5), 925950. doi: $10.2307 / / 556420$

ZHANG, M., Tansuhaj, P., Mccullough, J. (2009). International entrepreneurial capability: The measurement and a comparison between born global firms and traditional exporters in china. Journal of International Entrepreneurship, 7(4), 292-322. doi: I0. I007/s I0843-009-0042-I 